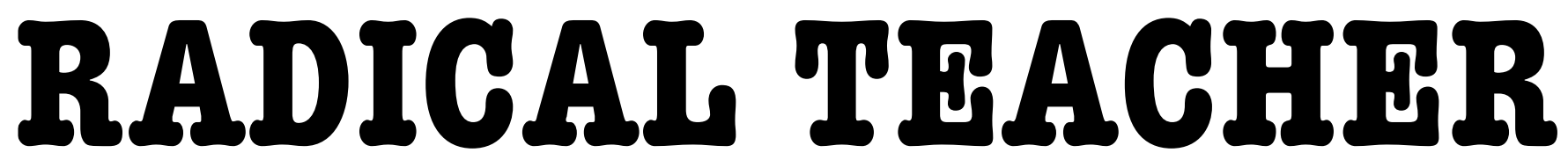

A SOCIALIST, FEMINIST, AND ANTI-RACIST JOURNAL ON THE THEORY AND PRACTICE OF TEACHING

\title{
English Society in the Eighteenth Century
}

(RADICAL TEACHER N0.61, 2001)

by James Thompson

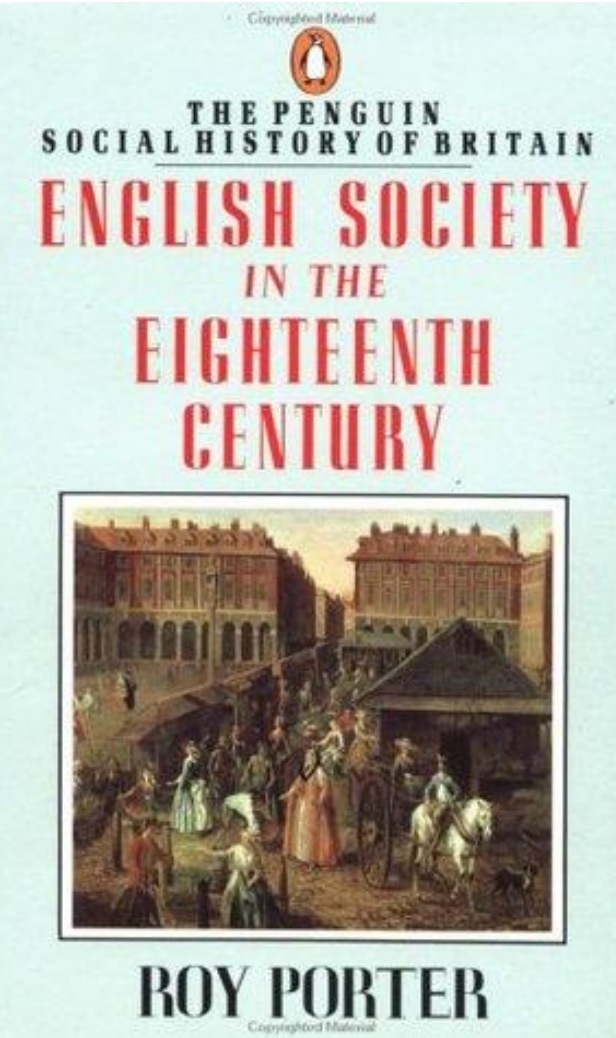

ENGLISH SOCIETY IN THE EIGHTEENTH CENTURY. ROY PORTER. (PENGUIN USA, 1990) 
English Society in the Eighteenth Century. Roy Porter. Penguin USA.

$\mathrm{T}$ o imagine a past, in any way different from the present, seems more difficult than ever before. Colleagues everywhere at every level describe students who appear to think that civil rights was a problem way back then that has been largely solved, just as sexism was something that used to plague us and now feminists have outlived their usefulness, that labor unions are an outmoded relic, socialism an ancient belief akin to that of the druids.

Class-consciousness is a delicate and therefore difficult (and all too easily patronizing) topic to introduce into classrooms where people often believe that they are middle class and therefore classless. In summer school each year, I teach a bread and butter eighteenth-century British literature survey class to a heterogeneous mixture of upper division undergraduates and a few English Education majors in the School of Education finishing their MATs. As secondary reading I assign parts of Roy Porter's English Society in the Eighteenth Century, a readable and accessible one-volume social history of early modern Britain.

After they read his chapter on social hierarchy, I ask the class to draw it on the board as a hierarchy, fitting groups, professions, and kinds of labor into his picture of the interlocking chains of deference and obligation that make up the Old Society. Upon picturing to our satisfaction this ladder, with its many little rungs of artisans, soldiers, small holders, grandees, weavers, shopkeepers, bishops, actresses, lawyers, servants, surgeons, and so on, we then try to draw our list and then arrange its present variant, with the initial aim of tracing what happens to specific figures -lawyers, doctors, actresses -- in the process of modernization. On facing blackboards, we end up with two vertical lists of professions, each organized into a rough status hierarchy, from bottom to top.

First, it becomes clear immediately that we have much greater difficulty drawing our own social hierarchy than we do that of mid-eighteenth-century England, which feels puzzling to all of us. Second -- and this is less obvious, but eventually evident as we work away -- we keep confusing wealth, celebrity, and prestige, as if in the older model, the clear markings of aristocratic order and land owning offered an explanation or a frame that the present structure lacked, organized as it is around the naked prestige of sheer wealth.

One of the issues we have to chew over is whether our sense of status is skewed by social prominence: how do we rank faceless wealthy fund managers with Oprah, for example? Because the ideal of the Old Society is the landed gentry and their agricultural estates, it is much easier to imagine face-to-face relations between the squire, his tenants, and his field hands than it is to imagine the much more abstracted, obscured, and distant relation between an individual laborer in Kuala Lumpur and a multinational corporation's CEO, much less to imagine the relation between that laborer and a stockholder in Dayton, Ohio. But one payoff in this exercise is that the former relation helps us to understand the latter two, if only by way of structural similarity: in all three relations, some are enriched by the labor of others.

More years ago than I care to remember, at a Marxist Literary Group meeting in Pittsburgh, where I first heard of such a thing as cultural studies, someone spoke of his goal -- to try and entice his students to imagine and desire a genuinely better way to live, rather than to desire more things. This still seems to me to be a worthy goal, and one intimately tied to both political memory and personal aspiration as envisioned through schooling and advancement. (oc) EY-NC-ND

ULLS D-Sonle
This work is licensed under a Creative Commons Attribution-Noncommercial-No Derivative Works 3.0 United States License.

This journal is published by the University Library System of the University of Pittsburgh as part of its D-Scribe Digital Publishing Program, and is cosponsored by the University of Pittsburgh Press.
RADICAL TEACHER
No. 113 (Winter 2019) 